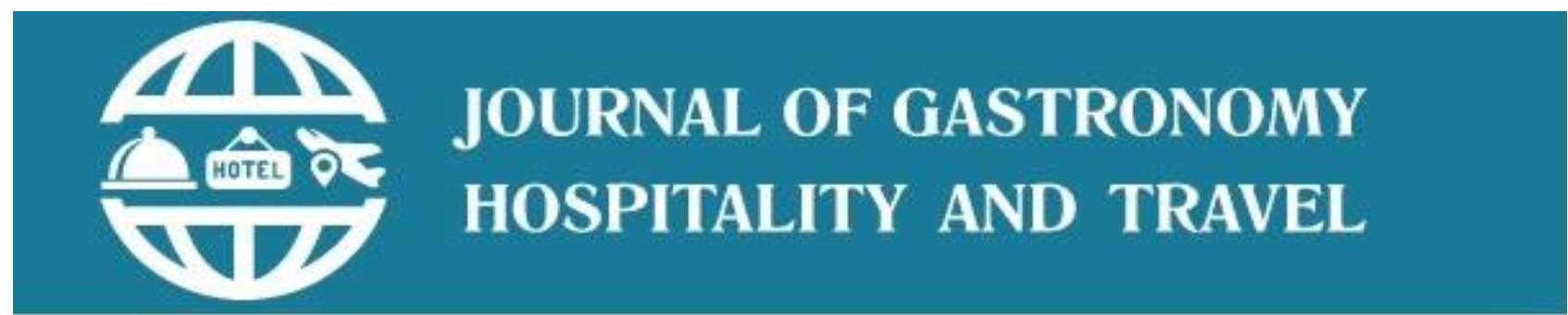

ISSN: 2619-9548

Journal homepage: www.joghat.org, http://dergipark.gov.tr/joghat

Journal of Gastronomy, Hospitality and Travel (JOGHAT)

2020 - Volume: 3 Number: 1

Page : 141-149

Received:04/05/2020

Revised:17/06/2020

Accepted: $21 / 06 / 2020$

\title{
Review Article \\ GASTONOMY TOURISM AS AN EMERGING NICHE MARKET IN UZBEKISTAN
}

Ian Patterson ${ }^{1}$ (orcid.org/0000-0002-9277-8164)

Hamid Turaev² (orcid.org/0000-0002-3792-2960)

\author{
${ }^{1}$ Visiting Professor, Silk Road International University of Tourism, Samalkand, Uzbekistan \\ ${ }^{2} \mathrm{Head}$, International Educational Programs Department, Silk Road International University of Tourism, Samalkand, Uzbekistan
}

\section{ABSTRACT}

Gastronomic tourism is creating increased interest as a new and emerging niche market. It is attracting large numbers of tourists (or foodies) who want to sample local cuisine and this is one of the major reasons for travelling to new and exotic locations. One of the motivating forces to travel both globally and locally is to gain in-depth knowledge of a country's local and rural cuisine. Many local dishes have been prepared according to traditional recipes which have been handed down over many centuries and have become an important means of learning about a region's culture and heritage. Gastronomy is also an important element of Uzbekistan's local culture and identity. The preparation of traditional dishes dates back to the ancient times of the 'Great Silk Road'. This paper concludes with suggestions to promote the importance of gastronomic tourism and to raise its profile as an emerging niche market in Uzbekistan.

Key Words: Gastronomy tourism; culture; heritage; Uzbekistan; traditional dishes; Great Silk Road; niche market.

\section{Introduction}

There is a general belief that the tourism potential of Uzbekistan is underutilized and performing at a lower level than its actual potential (Kapiki and Tarikulov, 2014). This is because over the past few years, the tourism industry has mainly concentrated on promoting its cultural, archeological and natural attractions as a means of attracting foreign tourists to the 'Silk Road' cities in the southern region of the State. These were the ancient locations and cities of the most direct trade route between China and Europe, which became known as the 'Silk Route' first established in early Roman times (Kantarci, Uysal and Magini, 2014).

There is little doubt that government support that had been afforded from the newly established State Committee of the Republic of Uzbekistan in 2016 has initially raised the country's profile as a new and exotic location to visit, which is based around its ancient civilizations and cultural traditions. The numbers of foreign visitors has increased substantially in recent years from 173,000 in 1996 ( $\$ 15$ million, $0.11 \%$ of GNP), to 5.35 million visitors in 2018 ( $\$ 1.31$ billion, 2.6\% of GDP) (World Data.info., 2018). Tourists stated that they were mainly attracted by the many unique

\footnotetext{
${ }^{1}$ To cite this document: Patterson, I. and Turaev, H. (2020). Gastonomy Tourism as An Emerging Niche Market in Uzbekistan, 3(1), 141-149. DOI: 10.33083/joghat.2020.38

Corresponding Author: ian.patterson@uq.edu.au
} 
architectural mausoleums, minarets and mosques in the ancient cities of Samarkand, Bukhara and Khiva; and generally chose a guided tour as the most popular one provided by local travel agencies (mfa, Uzbekistan, 2020).

Based on methodological approaches adopted by the United Nations Organization, tourism statistics were collected by the State Committee of the Republic of Uzbekistan for Tourism Development that has found that the majority of foreign tourists who arrive in Uzbekistan, generally undertake at least one standardized cultural tour program, and stay for only a brief amount of time (average duration of stay was 6.9 days) (Tourism, Uzbekistan, 2018). Kapiki and Tarikulov (2014) warned that this must be a major concern for tourism providers as, "...there is no guarantee that this small tourism flow arriving in Uzbekistan will not exhaust itself in some time". Thus, the researchers of this paper propose that if the government of Uzbekistan wants tourists to stay for a longer time period and encourage repeat visitations, they must support and promote the future development of new niche tourism markets. Gastronomic tourism is regarded as a new and emerging niche market which, if it is promoted successfully, is likely to be one of Uzbekistan's best possibilities of achieving long term economic and tourism stability.

This is because there are a growing number of travelers who are interested in not only exploring different cultures throughout the world, but also experiencing their unique cuisine and food products (World Tourism Organization 2012). Gastronomy tourism is now considered to be a niche or alternative form of tourism, which has often been included as a new or additional sector of the travel and tourism business (Ritchie and Crouch 2003). Du Rand, Heath and Alberts (2003) argued that a nation's identity is often reflected and strengthened by the food experiences that it offers.

Thus, the main purpose of this exploratory paper is to discuss the significance of gastronomy tourism as a niche tourism market, especially in regard to its role in the promotion of rural locations and agri-tourism; and to inform and update destination managers and policymakers in Uzbekistan about the latest findings that are linked to this emerging market segment. Finally new initiatives such as the development of associated travel routes will be discussed to determine whether they can be successfully developed to promote gastronomy tourism in Uzbekistan in the future.

This paper was based on an intensive review of the research literature which has included using an iterative search of multiple literature databases such as the Web of Science, Scopus and Google Scholar. Research papers that had been previously published on the development of gastronomic tourism in Uzbekistan, as well as specific research articles from a Proceedings of the International Conference 'Tourism and Education: Ways of their Interaction and Development' Silk Road International University of Tourism, Samarkand, Uzbekistan 25-26 November, 2019. The articles that were referred to in this paper were all published between 1997 and 2019. Each of these articles used secondary sources as well as a mixture of qualitative and quantitative research methods, and each was scrutinized by the researchers through an in-depth review of the selected research articles.

The next section of this article will discuss the following questions: what is gastronomy tourism? what is its importance in promoting the cultural significance of local foods? and how can gastronomic tourism assist in the revitalizing of local economies in rural areas?

\section{Gastronomy tourism}

Gastronomy tourism is a new and emerging phenomenon (Gheorghe, Tudorache, and Nistoreanu, 2014). Over the last few years, there has been increased interest in this niche market which is attracting large numbers of tourists (or foodies) to sample local cuisine and has been stated by them as the major reason for travelling. The word gastronomy is derived from the Greek word 'gastros' meaning stomach, and 'gnomos' meaning knowledge or law (Kivela and Crotts, 2006). One of the basic definitions of gastronomy tourism has simply been described as experiencing one's culture 
through food (Long, 1998). The World Tourism Organization concluded that gastronomy tourism has recently been described as an important area of growth, not only because food and drink are central to the tourist experience, but also because the concept of gastronomy tourism has evolved to include a wide range of cultural practices.

"Gastronomy tourism represents an opportunity to constantly revitalize and diversify tourism, promote local economic development, involve many different professional sectors and bring new uses to the primary sector. Hence, gastronomy tourism contributes to promoting and branding destinations, maintaining and preserving local traditions and diversities, and harnessing and rewarding authenticity." (World Tourism Organization, 2017, p. 14).

Richards (2012) discussed how gastronomy tourists desire experiences that incorporate both local and authentic foods and beverages, which are seen as the main motivating factors for travel that are associated with the areas that they visit. Clave and Knafou (2012) noted that the tourist experience transforms the gastronomic experience into the main focus of the trip which is seen in a context where mobility is becoming increasingly global as well as local.

Hjalager and Richards (2002) stated that gastronomic tourists were not only interested in satisfying their hunger and thirst, but furthermore, wanted to gain in-depth knowledge about local or regional cuisine, as well as wine and beverages that relate to a specific destination's particular cultural traditions. Ignatov and Smith (2006) further discussed how gastonomic tourism includes acquiring 'local knowledge' to help tourists understand a country's distinctive culinary culture. Hegarty and O'Mahony (2001) highlighted the cultural significance related to differences in ingredients, the way that food is prepared and preserved, and how food is served and eaten. Richards (2002) further observed that the food which people prepare and the way that they consume it, helps them to express their identity, and noted that meals and eating traditions are culturally bound.

Björk and Kauppinen-Räisänen (2014) explored the factors that help to contribute to the traveller's culinary-gastronomy experiences, focussing on a local food fair in Helsinki, Finland. Their study findings concluded that local food was regarded as an important tourist attraction and central to the tourist experience. This not only appeared to be true for those travellers who have a special interest in food and were extremely involved in gaining food experiences, but also for those who had a more casual attitude to food and eating. They concluded that food is an essential part of the local culture, which does not need to be extraordinary, so long as it is local, original and authentic.

Variety in the choice of dishes is an essential element for tourists to help them appreciate local cuisine (Chang, Kivela, and Mak, 2010). Quan and Wang (2004) discussed how culinary entities can transform their local selection of food into a tourist attraction. Traditionally, many local communities do not regard their cuisine in high regard, as it is generally viewed as not being sophisticated enough, and definitely not something a tourist might be interested in eating (Kapner, 1996). However, studies are now finding that there is increased interest in food (or gastronomy tourism) which is making a significant contribution to the economy of that specific market destination (Bessiere, 1998).

\section{Gastronomy tourism in rural settings}

This partnership between food and nature is mainly nurtured in the countryside, where food that is enjoyed in rural contexts has offered urban dwellers a chance to return to their rural foundations (Tregear, 2003). This reconnection with nature has become intrinsically connected with yearning for 'yesteryear' (Dann, 1996), where this nostalgic resurrection has become a particularly compelling discourse (Fox, 2007). Many of these rural dishes are prepared according to traditional recipes handed down from generation to generation over many centuries. They also based on a direct connection with nature, culture, religion and the lifestyle of local communities (Grigorova, Shopova and Timareva, 2016). 
As a result, gastronomy tourism is now becoming a fashionable niche market that is helping to restore the 'identity crisis' which many local communities are still experiencing. This is encouraging tourists to not only travel to rural areas and buy local products, but to eat in restaurants, shop at local markets and visit farms which can represent a sizable income for these local communities. In addition, educational events that focus on agriculture, culinary and gastronomic products such as the selling of cheeses, desserts and wine as well as food and wine festivals provide added attractions for tourists (Banjac, Kalenjuk, Tesanivic et al., 2016).

Sims (2009) conducted research in two regions in the United Kingdom: the Lake District and Exmoor and argued that local food can play an important role in the sustainable tourism experience, because it appeals to the visitor's desire for authenticity within the holiday experience. After conducting qualitative interviews with a sample of both tourists and food producers, Sims (2009) concluded that 'local food' has the potential to enhance the visitor experience by connecting consumers to the region and its perceived culture and heritage. Thus, local dishes of a specific region have become an important means of getting to know the area and to learn more about different cultures (Gyimothy, Rassing and Wanhill, 2000). Gyimothy, et. al. (2000) stated that respondents indicated that restaurants were a significant and decisive motive for their choice of visiting a particular destination.

Because of the increased popularity of gastronomy tourism, many destinations are promoting themselves as major centres for food and culture and using traditional food and beverages as added attractions (Robinson and Getz, 2012). This is resulting in an increasing number of tourist destinations becoming very sought after because of their unique culinary and gastronomy (Hjalager, 2002). For example, Sahin (2015) discussed the growth in gastronomy tourism as an alternative tourism field in Turkey. He stated that gastronomy tourism helps support the development of rural areas that consists of seven regions that have different climates and vegetation. This has resulted in the great diversity of local taste and flavour of Turkish cuisine and which has made it is one of the top three cuisines in the world.

The possible benefits for these destinations are likely to result in increased visitor arrivals and length of stay; a new competitive advantage or unique selling proposition; more sales across the complete range of travel including hospitality, transport and retail; increased community pride, positive media coverage and increased taxation revenue (Yeoman, McMahon-Beattie, Fields et. al, 2015). Furthermore, gastronomy tourism is seen as being an integral part of the culture of communities and destinations, that Ignatov and Smith (2006) referred to as its roots that grow deeply and conveys something that is indigenous, perhaps even unique about a specific destination.

\section{Gastronomic travel routes}

Is defined as travel in order to search for, and enjoy prepared food from different food producers along a wine and/or food gastronomic trail or route (Vas and Nijkamp, 2016). These may include visiting a number of products or tourism sites such as factories and restaurants that are listed in tourist guides and specialize in a specific type of food, product or gastronomic event such as food (farmers) markets and fairs.

This route may also inform tourists about other sites and attractions that they might be attracted to visit, thereby promoting economic development throughout the region. The idea is to bring together different types of tourist attractions and to offer tourists a convenient package so that they will stay longer in the area in contrast to places where only one type of attraction is promoted (Gheorghe, Tudorache, and Nistoreanu, 2014).

Gastronomic travel trails are good examples of the cooperation that can exist between agriculture and tourism. For example, the Bregenzerwald cheese walking trail in lower Austria offers a variety of different products to tourists. Bregenzerwald is an association of alpine dairy farmers and 
cheese-makers, restaurants, museums and cable car operators, as well as members of the tourism industry and partners from the business world of trade and commerce. There are over 160 partners that make up the KäseStrasse network, that have joined together to maintain and preserve the regional culture (Mehichyer-Cech, 2005).

Williams, Williams and Omar (2014) discussed the process of establishing gastronomy travel routes and trails. They suggested that by utilising existing food resources and local experts, a gastro-tourism trail or route can be launched, even in remote parts of the world provided that key infrastructure was in place. Regional towns and villages have found that start-up risks were minimal provided that the following three basic infrastructure elements existed: (1) clean water, healthy food handling, and effective sanitation practices (2) safe transport of people to and from various experiences, and (3) interactive internet capabilities to clearly articulate message and brand promise. Williams, et. al. (2014) concluded that if a geographic area is able to identify at least six hosts with interesting food-related opportunities, who are willing to loosely organise and continuously communicate, a gastronomic tourism trail becomes a viable possibility.

\section{Gastronomic tourism in Uzbekistan}

Gastronomy tourism is regarded as an emerging area of academic study and as a result, very few articles have been published in the databases that pertain to Uzbekistan. Most researchers have focused on the cultural and heritage attractions of Uzbekistan (Hasanovich, 2017). However, Xidirova and Turakulov (2019) have suggested the need to promote other types of tourism such as gastronomy tourism, because they felt that tourists limit themselves with visits to only historical and architectural monuments and that they need to also experience gastronomic, natural and agri-tourism.

Abduvakhidova and Yunusova (2019) stated that gastronomy is an important element of Uzbekistan's local culture and identity, which has for past centuries has absorbed local traditions and different cultures, as well as culinary traditions. They stressed the importance of developing gastronomy tourism in Uzbekistan so that visitors from around the world are able to enjoy this unique cuisine as well as becoming acquainted with the culture and history of the region. Abduvakhidova et. al. (2019) further identified the connection between gastronomy and tourism, as it helps to increase the influx of tourists, to prolong the stay of tourists and to increase profits from tourism.

Several authors confirmed that Uzbekistan has the potential to develop gastronomy tourism, because of its unique national cuisine and tradition of good hospitality. Abduvakhidova and Sherzod (2019) affirmed that Uzbek cuisine is one of the most well-known aspects, and reflects some of the most essential aspects of Uzbekistan's culture. It is also regarded as one of the most savoriest and tasty cuisines in Central Asia. Abduvakhidova and Yunusova (2019) concluded that, "Food reveals the secret of the spirit of the people and helps to understand their mentality" (p. 150)

Uzbek cuisine is regarded as one of the richest in the East and shares the culinary traditions of Turkic people across Central Asia. The major cities are located on the trade caravan routes of the Great Silk Road, and for many centuries Uzbekistan absorbed the most interesting and unusual dishes of different countries because of the fact that these Uzbek cities attracted a large number of merchants who arrived from Asia. As a result, dishes from other nations have infiltrated into Uzbek cuisine, and many have evolved over the years into national dishes. In addition, the different preparation of dishes which are now identical in name, dates back to the ancient times of the Great Silk Road, when the mixture of traditions, new national dishes and spices turned each of the ancient cities into separate culinary regions.

Every region in the Republic of Uzbekistan has its own specialties for the cooking of national dishes. Xidirova et al. (2019) stated that the most famous dishes are plov, manti, dolma, hasip, lamb kebebs, somsa and famous bread from the tandoor. Overall, plov (or pilaf) is considered to be the most famous dish of Uzbekistan. The main ingredients are rice, meat, carrots and onions. It is prepared 
differently in different regions, in Tashkent it is made with dark rice and roasted at the beginning, while in the Samarkand region it is cooked with light rice, meat, carrot and rice in layers and is steamed. The process of roasting the meat, onions and other ingredients of pilaf is also different in other regions.

Several suggestions have been proposed by these researchers to promote the importance of gastronomic tourism in Uzbekistan.

1. A promotional campaign needs to be implemented that explains the benefits of gastronomy tourism in Uzbekistan with a suggested title of 'Along the Silk Road in Uzbekistan'. This could be similar to the 'Great Tea Road Project' that Russia, Mongolia and China are working together to promote. This project involves traveling by train from China to the Urals in Russia. Its main aim is to educate tourists about the historical and cultural heritage of these three countries (Abduvakhidova and Yunusova, 2019).

2. Promote gastronomy tourism to the media by: inviting members of the telecafe TV channel to prepare a program on Uzbek cuisine, gastronomic traditions and customs as well as the best Uzbek cafes and restaurants: and inviting journalists from specialized foodie publications, and culinary bloggers from foreign countries to visit the existing routes of gastronomic tours in Uzbekistan (Abduvakhidova and Yunusova, 2019).

3. The State Committee for Tourism Development could issue certificates to restaurants that submit at least three different recipes of dishes that are not available anywhere else in the world. Tour firms could advertise restaurants with their logo on for tourists, as well as stating the price of these meals (Xidirova and Turaakulov, 2019).

4. Tour operators to prepare maps to show the main gastronomy trails and routes to provide tourists with knowledge about places to visit in their travels around rural areas (Abduvakhidova and Sherzod, 2019).

\section{Conclusion}

Local cuisine that is unique can help to develop and market a particular destination, and because of this it can introduce many aspects of its regional culture to tourists. Gastronomy tourist activities can be central to make a tourist's trip a unique one, and helps a destination stand out so that it creates an excellent reputation. In addition, gastronomy related activities such as food and harvest festivals, culinary courses and cultural museums can also play an important role in marketing a destination.

Gastronomy tourists desire experiences that incorporate both local and authentic foods and beverages, as well as helping them to acquire 'local knowledge' about the region and its distinctive culinary culture. Many local dishes that have been prepared in rural areas are based on traditional recipes handed down over many centuries, with their ingredients incorporating a direct connection with nature, culture, religion and the lifestyle of local communities. Gastronomy travel routes or trails need to be developed to encourage increased tourist visitation to a rural area. Gastronomy tourist trails are well established in Europe and are listed in tourist guide booklets that inform about in specific types of food, products and/or gastronomic events. This information guide help to inform tourists about recommended sites and attractions that they might be interested in visiting, so that they will stay for a longer time period in the area in contrast to places that only promote one type of attraction.

Gastronomy tourism can be an important element of Uzbekistan's local culture and identity. Uzbek cuisine is well-known and regarded as one of the most savoriest and tasty cuisines in Central Asia. Over the centuries, many of the traditional dishes from other nations have infiltrated into Uzbek cuisine which dates back to ancient times. These dishesare likely to attract visitors from all over the world who will be able to enjoy this unique cuisine as well as helping them to become acquainted with the culture and history of the region.

There is general agreement among tourist providers that visitors who decide to travel to Uzbekistan are mainly interested in cultural and historical attractions, and generally undertake the 
more popular cultural and heritage tours provided by local travel agencies (i.e., to Tashkent, Samarkand, Bukhara and Kiva). However, tourism statistics have shown that the majority of foreign tourists only visit Uzbekistan once, take standardized cultural tours and stay for only a short duration. This should be a major concern for tourism providers. If the Government of the Republic of Uzbekistan, and associated tourism providers want tourists to stay for a longer period and to encourage repeat visitations, they must work together by organizing a one-day Conference with the Association of Gastronomic Tourism of Uzbekistan, staff and students from the Silk Road International University of Tourism or other Universities that have an interest in Tourism Studies, and tourism providers to develop a set of recommendations to promote the gastronomy tourism industry. It is hoped that this initiative can be implemented in the future to help Uzbekistan build its image and brand, and to work toward a more diversified tourism industry.

\section{References}

Abduvakhidova, N., \& Yunusova, M. (2019). Gastro tourism as an important factor of tourism development in Uxbekistan. Proceedings of the International Conference 'Tourism and Education: Ways of their Interaction and Development' Silk Road International University of Tourism, Samarkand, Uzbekistan 25-26 November, 2019 (pps. 101-105).

Abduvakhidova, N., \& Sherzod, S. (2019). Gastronomic traditions in Uzbekistan. Proceedings of the International Conference 'Tourism and Education: Ways of their Interaction and Development' Silk Road International University of Tourism, Samarkand, Uzbekistan 25-26 November, 2019 (pps. 170-173).

Banjac, M., Kalenjuk, B., Tesanivic, D., Gagic, S. \& Cvetkovic, B. (2016). Gastronomic tourism in rural areas of Vojvodina (Serbia). Turizam, 20(4), 180-191.

Bessire, J. (1998). Local development and heritage: Traditional food and cuisine as tourist attractions in rural areas. European Society for Rural Sociology, 38(1), 21-34.

Bjork, P., \& Kauppinen-Raisanen (2014). Culinary-gastronomic tourism-a search for local food experiences. Nutrition and Food Science, 44(4), 294-309.

Chang, R., Kivela, J., \& Mak, A. (2010). Food preferences of Chinese tourists. Annals of Tourism Research, 37(4), 989-1011.

Clave, S. A. \& Knafou, R. (2012). Gastronomy, tourism and globalization. Via (3) International Interdisciplinary Review of Tourism. Retrived at: http://viatourismreview.com/wcontent/uploads/2015/06/Tourisme_gastronomie_mondialisatio n_EN.pdf (Accessed 2nd May, 2020)

Dann, G. (1996). The language of tourism: a sociolinguistic perspective. Wallingford: CABI.

Du Rand, G., Heath, E., \& Alberts, N. (2003). The role of local and regional food in destination marketing. Journal of Travel and Tourism Marketing, 14(3-4), 97-112.

Fox, R. (2007). Reinventing the gastronomic identity of Croatian tourist destinations. International Journal of Hospitality Management, 26(3), 546-559.

Gheorghe, G., Tudorache, P., \& Nistoreanu, P. (2014). Gastronomic tourism, a new trend for contemporary Tourism. Cactus Tourism Journal, 9(1), 12-21.

Grigorova, Z., Shopova, I., \& Timareva, S. (2016). Rural food tourism, Balkan and Near Eastern Journal of Social Sciences, 
Gyimothy, S., Rassing, C., \& Wanhill, S. (2000). Marketing works: a study of restaurants on Bornholm, Denmark. International Journal of Contemporary Hospitality Management, 12, 371-379.

Hasanovich, M. H. (2017). Tourism in Uzbekistan: Opportunities and new challenges. Section 17: Economics and Management Retrieved at: https://cyberleninka.ru/article/n/tourism-inuzbekistan-opportunities-and-new-challenges (Accessed 19th March, 2020).

Hegarty, J. A., \& O’Mahony, G. B. (2001). Gastronomy: A phenomenon of cultural expressionism and an aesthetic for living. International Journal of Hospitality Management, 20(1), 3-13.

Hjalager, A.-M. (2002). Repairing innovation defectiveness in tourism. Tourism Management, 23(5), $465-474$.

Hjalager, A-M. \& Richards, G. (eds.). (2002). Tourism and gastronomy. London: Routledge.

Ignatov, E., \& Smith S. (2006). Segmenting Canadian culinary tourists. Current Issues in Tourism, $9(3), 235-255$.

Kapiki, S., \& Tarikulov, M. (2014). Development prospects of Uzbekistan's tourism and hospitality industry by utilizing the EU experience. Proceedings of the "International Conference on Tourism Milestones - Preparing for tomorrow", Sharjah, United Arab Emirates. Retrieved at: https://papers.ssrn.com/sol3/papers.cfm?abstract id=2546187 (Accessed 25 ${ }^{\text {th }}$ March, 2020).

Kapner, Z. (1997). Understanding. Restaurant Business, July 15.

Kantarci, K., Uysal, M., \& Magnini, V. (2014). Tourism in Central Asia: Cultural potential and challenges. Apple Academic Press.

Kivela, J., \& Crotts, J. (2006). Tourism and gastronomy: Gastronomy's influence on how tourists experience a destination. Journal of Hospitality \& Tourism Research, 30(3), 354-377.

Long, L. M. (1998). Culinary tourism: A folkloristic perspective on eating and otherness. Southern Folklore 55(3): 181-204.

Meyer-Cech, K. (2005). Regional co-operation in rural theme trails. In D. Hall, I. Kirkpatrick, \& M. Mitchell Rural Tourism and Sustainable Business. Channel View Publ.

MFA Uzbekistan (2020). Tourism in Uzbekistan. Retrieved at: https://mfa.uz/en/uzbekistan/330/ Accessed $5^{\text {th }}$ June, 2020.

Quan, S., \& Wang, N. (2004). Towards a structural model of the tourist experience: an illustration from food experiences in tourism. Tourism Management 25(3), 297-305.

Richards, G. (2002). Gastronomy: an essential ingredient in tourism production and consumption? In A. Hjalager \& G. Richards (eds.), Tourism and gastronomy (pp. 3-20). London: Routledge.

Richards, G. (2012). Food and the tourism experience: major findings and policy orientations. In D. Dodd, (ed.) Food and the Tourism Experience. OECD, Paris, (pp. 13-46).

Ritchie, J. R., \& Crouch, G. (2003). The competitive destination. A sustainable tourism destination. Oxfordshire, UK. CABI. 
Robinson, R. N., \& Getz, D. (2012, March). Getting involved: 'Foodies' and food tourism. In CAUTHE 2012: The new golden age of tourism and hospitality; Book 2; Proceedings of the 22nd Annual Conference (p. 176). La Trobe University, Victoria, Australia.

Sahin, G. (2015). Gastronomy tourism as an alternative tourism: As assessment of the gastronomy tourism potential of Turkey. International Journal of Academic Research in Business and Social Sciences, 5(9), 79-105

Sims, R. (2009). Food, place and authenticity: local food and the sustainable tourism experience. Journal of Sustainable Tourism, 17(3), 321-336.

Tregear, A. (2003). From Stilton to Vimto: Using food history to re-think typical products in rural development. Sociologia Ruralis, 43(2), 91-107. Retrieved at: https://doi.org/10.1111/14679523.00233. (Accessed $2^{\text {nd }}$ May, 2020)

UNWTO (2012). Global Report on Food Tourism, AM Reports, 4, 10-11. Retrieved at: http://dtxtq4w60xqpw.cloudfront.net/sites/all/files/pdf/food_tourism_report.pdf (Accessed $2^{\text {nd }}$ May, 2020).

Williams, H., Williams, R., \& Omar,M. (2014). Gastro-tourism as destination branding in emerging markets. International Journal of Leisure and Tourism Marketing, 4(1), 1-17.

World data (2018). WorldData. info Retrieved at https://www.worlddata.info/ (Accessed May 2nd, 2020).

World Tourism Organization (2017). Affiliate Members Report, Volume sixteen - Second Global Report on Gastronomy Tourism. UNWTO, Madrid.

Xidirova, G., \& Turaakulov, F. (2019). Establishment of a new stage of development of gastronomic tourism in Uzbekistan. Proceedings of the International Conference 'Tourism and Education: Ways of their Interaction and Development' Silk Road International University of Tourism, Samarkand, Uzbekistan 25-26 November, 2019 (pps. 146-151).

Yeoman, I., McMahon-Beattie, U., Fields, K., \& Meethan, K. (eds). (2015). The future of food tourism: Foodies, experiences, exclusivity, visions and political capital (Vol. 71). Bristol: Channel View Publications. 